\title{
TERRAIN BASED PARAMETRIZATION \\ OF ROMAN ROAD NETWORKS
}

DOI: https://doi.org/10.18509/AGB.2020.19

UDC: 625:528.931]:94(37)(497)

\section{Gspurning Josef}

University of Graz, Department of Geography and Regional Sciences; Graz, Austria

Corresponding author: josef.gspurning@uni-graz.at

submitted: 06.03.2020

accepted: 23.05 .2020

published: 15.09 .2020

\begin{abstract}
Since the spatial turn and the associated reassessment of geographic information systems, transport and mobility optimizations in particular can be solved with the help of spatial analysis toolboxes such as Transportation Network Analysis (in vector cases) or the Least Cost Path approach (LCP, in raster cases). In addition to its almost universal applicability, especially the LCP method shows some often discussed weaknesses due to its independence from given path networks. In particular, the apparent conceptual simplicity of the method (reduction to a single controlling factor, impedance) makes the result highly dependent on the selection and parameterization of the influencing factors like costs, capability or terrain. This paper tries to overcome the disadvantages of this method by proposing a new way in the terrain based determination of impedance. Using the example of the ancient highway called Via Egnatia (historical transport route that once connected the Adriatic Sea with the Bosporus) the parameterization of the Roman route is analyzed. The crossing of the Balkans and the Dinaric Mountains with the necessary overcoming of relatively large differences in relief makes this route particularly suitable for the investigation of the relationship between relief and parameters of the real transport route. Special attention is given to the statistical analysis of the optimal sampling distances for the respective terrain types as a crucial point for the parameterization of impedance.
\end{abstract}

Keywords: Roman roads, transportation network modelling, route layout factors, relief parametrization, Via Egnatia

\section{INTRODUCTION AND MOTIVATION}

For a variety of reasons, distance - or better overcoming the distance has an absolutely remarkable significance in almost every aspect of human life. Whether as a determining factor for personal time management, as a controlling factor for the range of influence of people, events or goods or indirectly as a cost factor, distance has been and still is an omnipresent aspect of life as we know it. It is therefore obvious that the trivial as well as the scientific confrontation with this key concept of geography is repeatedly the subject of a broad and multidisciplinary discussion. Although the

\section{SCOPE OF THE INVESTIGATION}

Regarding the characteristics of mobility and transport in antiquity, Verhagen et al. [1] provide a comprehensive overview of possible influencing factors on the movement capability. Besides the natural environment (topography/slope, vegetation, hydrological aspects etc.) the authors also assess the associated parameters are in fact largely known, the scientific debate on this subject area is far from complete due to the topicality of the subject. This contribution is intended to discuss existing knowledge from the perspective of orography, with a focus on the Roman transport network, and to supplement and extend this knowledge where necessary. The obvious disadvantage of the comparatively poor state of source material for certain aspects is compensated by the less complex structure of the influencing factors .

existence or density of infrastructural facilities (mansiones, mutationes and stationes) as well as aspects of safety, control and orientation as features worthy of consideration. From the GIS analyst's point of view, it can be stated that all the variables mentioned can be modelled and analyzed in 
principle, but that this possibility is relatively limited due to the lack of suitable data. This applies not only to the often missing evidence, but also to the correct handling and processing of the more dynamic parameters (vegetation, river courses etc.), where historical appropriate modelling is considerably more difficult. In contrary the approach presented here attempts a completely different way of thinking. It is based on the idea of focusing mainly on the two parameters that are, so to speak, facts: the relief on the one hand, which is undoubtedly the most formative element, and which is also relatively stable in terms of its shape against changes, and the historical route itself, which otherwise the result of the relevant analyses - is here the starting point of a kind of reverse engineering process. Based on these prerequisites, all those characteristic values that can be derived from the terrain model or the route are available for further analyses.

\section{The Via Egnatia}

The Via Egnatia as an object of study is very suitable as a basis for researching the parameterization for several reasons; on the one hand, the route is very good reviewed in the western part [2]; in the remaining part it is at least sufficiently studied. This applies not only to the descriptions by ancient authors (e.g. Polybios, Cicero) or by other ancient documents (like the Tabula Peutingeriana, the Antonine or the Bordeaux Itinerary) and architectural relics (milestones, ruins), but also to the documentation by scientists of the twentieth and twenty-first century $[3,4]$. Furthermore, the course of the road between the Adriatic Sea and the Aegean Sea across

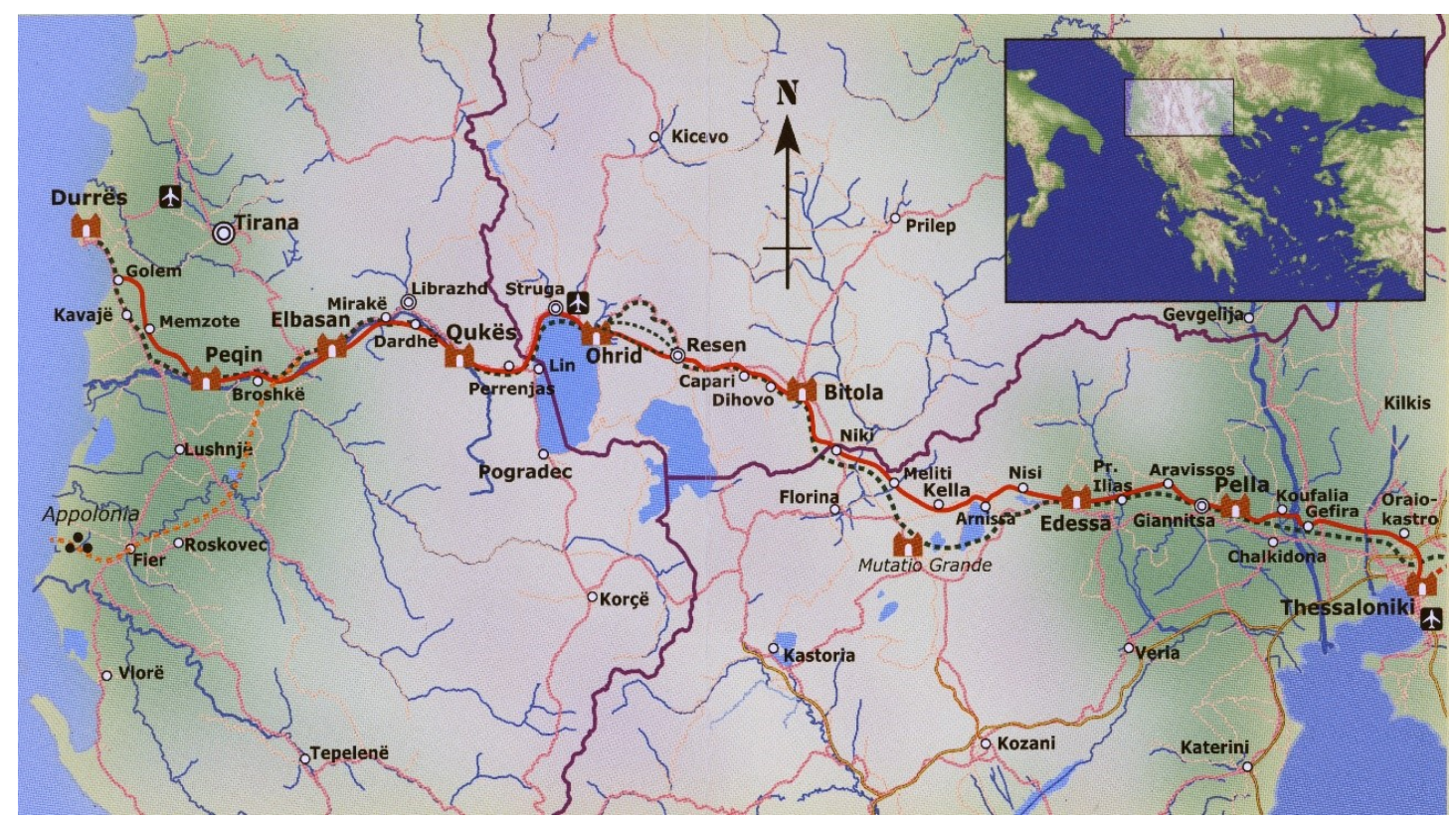

Figure 1. The route of the Via Egnatia from Dyrrachium/Durres to Thessalonike/ Thessaloniki (Scource: www.viaegnatiafoundation.eu)

the Balkan peninsula is ideally suited for investigating the influences of the terrain on the route as mentioned above [Fig.1]. Starting from Dyrrachium, the Via Egnatia runs eastwards viLychnidos, Herakleia Lyncsestis, Edessa, Pella, Thessalonike, Amphipolis and Neapolis t Perinthos west of Byzantium [4], crossing wide coastal plains and hilly regions, but also the mountain ranges of the Dinaric Alps. The origins of this 754 Roman miles (about $1070 \mathrm{~km}$ ) long arterial road probably go back to older predecessors, but the actual Via Egnatia was only built as a Roman road between
146 and $120 \mathrm{BC}$ under the rule of the proconsul of Macedonia, Gnaeus Egnatius. On the one hand it represents the logical extension of the Via Appia and on the other hand it works as the most important supply line for the military protection of the newly acquired territories conquered by Rome during the eastern expansion in the following 100 years [5]. In the course of time, as Roman rule over the southeastern part of Europe became more and more secure, the road network received an increasing economic revaluation. The design features of the transport route follow the structure well known 
from other Roman roads: with respect to the terrain as straight as possible, partly paved or graveled and if necessary also drained. The width of the road ranges from two to three meters in the mountains to eight meters in the flat sections of the lower terrain. As a result of the high technical effort involved, the construction of bridges was avoided wherever possible, although relics of specimens with a considerable span (about $150 \mathrm{~m}$ ) exist on the route. During the Roman Empire, several phases of repair, extension and infrastructural upgrades are documented. The importance of the traffic route was significantly increased by the elevation of Constantinople as a second Rome and the associated upgrading of the Balkans, which was further enhanced by pilgrimages and crusades during the subsequent centuries. In Ottoman times, despite the expansion of the infrastructure (caravanserais, mosques, guides and security personnel), the transport route tended to lose importance because, on the one hand, the Ottoman transport system largely dispensed with transport wagons and the empire tended to orient itself politically and militarily towards the northwest. According to this, more importance was also attached to the branch of the road turning north at Thessalonike. Partly for this reason the present study concentrates on the road section between Dyrrachium and Thessalonike.

\section{DISCUSSION OF THE METHODS}

In general, the search for the optimal route is carried out with the help of two conceptually very different approaches. The conventional network analysis is based on a special form of the vector model (the network data model) which is less based on the geometrical/ topographical properties of the features than on concepts like adjacency, connectivity and impedance. The result of the analysis is determined attribute-based by applying

\section{Cost Surface and Least Cost Path}

A cost surface serves as a model representation of reality. However, as with any model of reality, it is not possible to give an accurate representation of reality. However, depending on the objective of an analysis, parameters have to be chosen in order to implement this in the best possible way according to the objective. In the present case, a cost surface is to be parameterized in such a way that the

\section{Data basis}

In order to take into account, the importance of the digital terrain model, appropriate requirements were set for the data material to be used; on the one hand, it should be possible to cover the entire route with a data set of uniform quality, and on the other hand, the data set should guarantee the highest possible resolution. For these reasons, the products of the SRTM (Shuttle Radar Topography Mission) were used, in which the elevation information is stored in *.hgt tiles with a resolution of $1 "$ (1 arcsecond, corresponding to approximately $20 \times 30$ meters). Subsequently, the tiles covering the survey area were combined and resampled to $25 \mathrm{~m}$ by $25 \mathrm{~m}$, resulting in a file size of about 26 megabytes per tile. The coordinate reference system of the final ArcGIS grid was first EPSG:4326 (Geodetic Datum: WGS 84), later UTM34N (WGS 84). The vertical resolution of the data is 1 meter. The Via Egnatia route was initially represented by relevant GPS tracks in GPX format from the Via Egnatia Foundation [6]. These vector data were projected according to UTM34N, converted into the shape format widely used in geoinformatics and additionally adapted with the help of available current documentation [7,8]. Furthermore, topographic maps of the scales 1: 50000 and 1:100000 served as a supplementary cartographic basis.

graph-theoretical principles by selecting the optimal route out of a given set of possibilities. Apart from the fact that the parameterization can cause certain difficulties, it is precisely this property that makes network analysis appear less suitable for the present problem. In contrast, the Least Cost Path (LCP) method uses raster data and attributes linked to these raster cells to determine the optimal route based on a predefined minimum.

orographic conditions of the environment affect an actor. By the means of least cost analysis, the route should be calculated which causes the least effort (i.e. in terms of costs, energy etc.) for the actor. Basically, cost surfaces can be created in two ways. On the one hand on the basis of a vector model and on the other hand on the basis of a raster model [9, 10]. In most cases the parameterization is done 
based on a raster model. In the raster model, a suitable metric can be chosen for the distance transformation: Euclidean metric, Manhattan metric or a metric that includes the diagonal neighbors (8-neighborhood) in addition to the Manhattan metric (4-neighborhood of the raster cells). In addition, travel costs or travel times can also be considered as cost surfaces. Cost surfaces contain information about the varying effort per cell that must be made to cover a distance. However, the accuracy of the result depends directly on the resolution (mesh size) of the grid. Basically, the creation of a cost surface is divided into three steps: standardization, weighting and combination [11]. A cost surface normally consists of several parameters. To be able to compare them with each other and combine them into a single surface, all individual costs must first be standardized. An accumulated cost surface calculates the accumulated minimum costs for each cell of the grid, starting from a starting cell. It is the basis for

\section{Terrain-based parameterization of the route}

For the reasons explained above, the approach presented here uses neither the conventional network analysis nor the LCPA, but is based on two fundamental assumptions, on a doubtlessly proven knowledge about the alignment of the road and - on the fact that the design of the Roman transport network follows certain criteria. Apart from the requirement for the shortest possible connection between two locations (within certain tolerances), it can be assumed that the height difference (gradient) to be overcome should remain minimal and even. In addition, it can be assumed that the number and

\section{PRACTICAL IMPLEMENTATION OF THE ANALYSES}

The analytical implementation of the presented concept takes place in several steps. After a basic definition of the natural dimensions, the calculation of the terrain parameters relevant for the investigation is carried out; these are the gradient as a measure of the steepness and the horizontal curvature as a measure of the curvature of the terrain [14]. Both calculations belong to the standard repertoire of conventional GIS packages, least cost paths, or least cost path analysis (LCPA) [12]. The cost of travelling from one node to the next depends on the spatial orientation of the nodes. The calculation of the increase in costs is possible horizontally and vertically (Rook's case) or in addition also diagonally. (Queen's case). For each processing step, the value is entered in the accumulated cost surface. This process is carried out step-by-step for all neighbors of the initial cell. This results in an essential advantage of this method: The determination of the optimal route in terms of the specification is possible independently of any preset route specifications. However, this is also the greatest weakness of the concept. The quality of such a result depends exclusively on how well weighting, standardization and combination can be adapted to the real conditions [13]. It is obvious that this optimization becomes more and more difficult as the number of layers involved increases.

radii of curvature of the curves should be as small as possible. Good visibility of the route, easy recognizable (natural) landmarks and potential locations for watchtowers would be further parameters that could be derived directly from the elevation model. In addition, by formulating an appropriate set of rules and regulations, complex constructions (bridges) can be avoided, as can the routing through alluvial, swampy terrain. However, the latter - as well as vegetation and historically existing infrastructure - were not taken into account.

whereby the first mentioned parameter is of particular importance in two respects: on the one hand it is important for the route characteristics [15], but on the other hand it is also a measure for the roughness of the terrain or for the type of terrain [16]. In a final step, the derived parameters are transferred to the route graph and the actual evaluation takes place. 


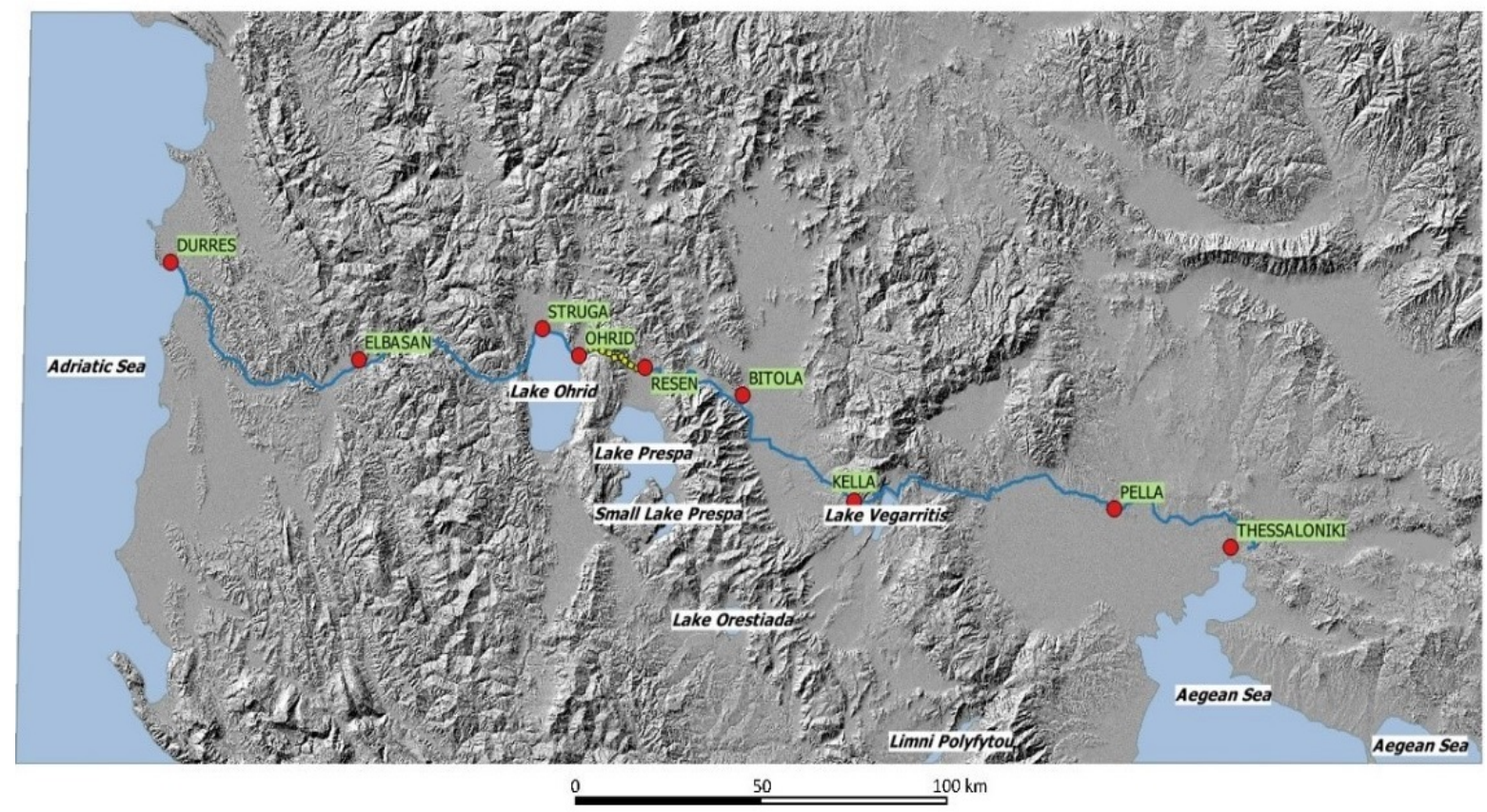

Figure 2. Relief characteristics of the investigation area. The yellow dotted line segment indicates the assumed summit of the Via Egnatia (blue solid line).

\section{Relation between route and relief}

In terms of altitude, both the start and finish of the section of the Via Ignatia considered for the study are at sea level [Fig. 2]. Apart from the unrealistic possibility of a relatively flat route along the coastline, height differences must be overcome. An evaluation of the elevation model shows that on the approximately $507.5 \mathrm{~km}$ long route between Dyrrachium and Thessaloniki, with optimal use of the relief conditions (between Velgosti and Resen), at least $1588 \mathrm{~m}$ height difference must be overcome; a large part of the route lies in the height range between $0 \mathrm{~m}$ and $500 \mathrm{~m}$ above sea level.

\section{Slope based relief classification}

In connection with the evaluation of the terrain, the question of the spatial resolution with which the attributes relevant for the investigation should be transferred to the route arises. For understandable reasons, this sampling distance (equivalent to the length of the route segments to be evaluated) should be small enough on the one hand to be able to map topic-relevant steeps in the terrain, but on the other hand should be higher than the resolution of the underlying grid in order to keep the amount of data to be analyzed within a reasonable range.

Therefore, the basic parameters were determined for the distance range between 25 and $10000 \mathrm{~m}$, but for the further analyses only the segment lengths 50 $\mathrm{m}, 100 \mathrm{~m}$ and $250 \mathrm{~m}$ were used. In view of the landscape characteristics of the study area, it can be assumed that these different landscape units also show different behavior. For this reason, the author follows $\mathrm{Wu}$ et al. in this question, who prove in their study that the slope and range parameters are best suited for terrain partitioning based on orographic heterogeneity among thirteen comparable parameters [17]. 


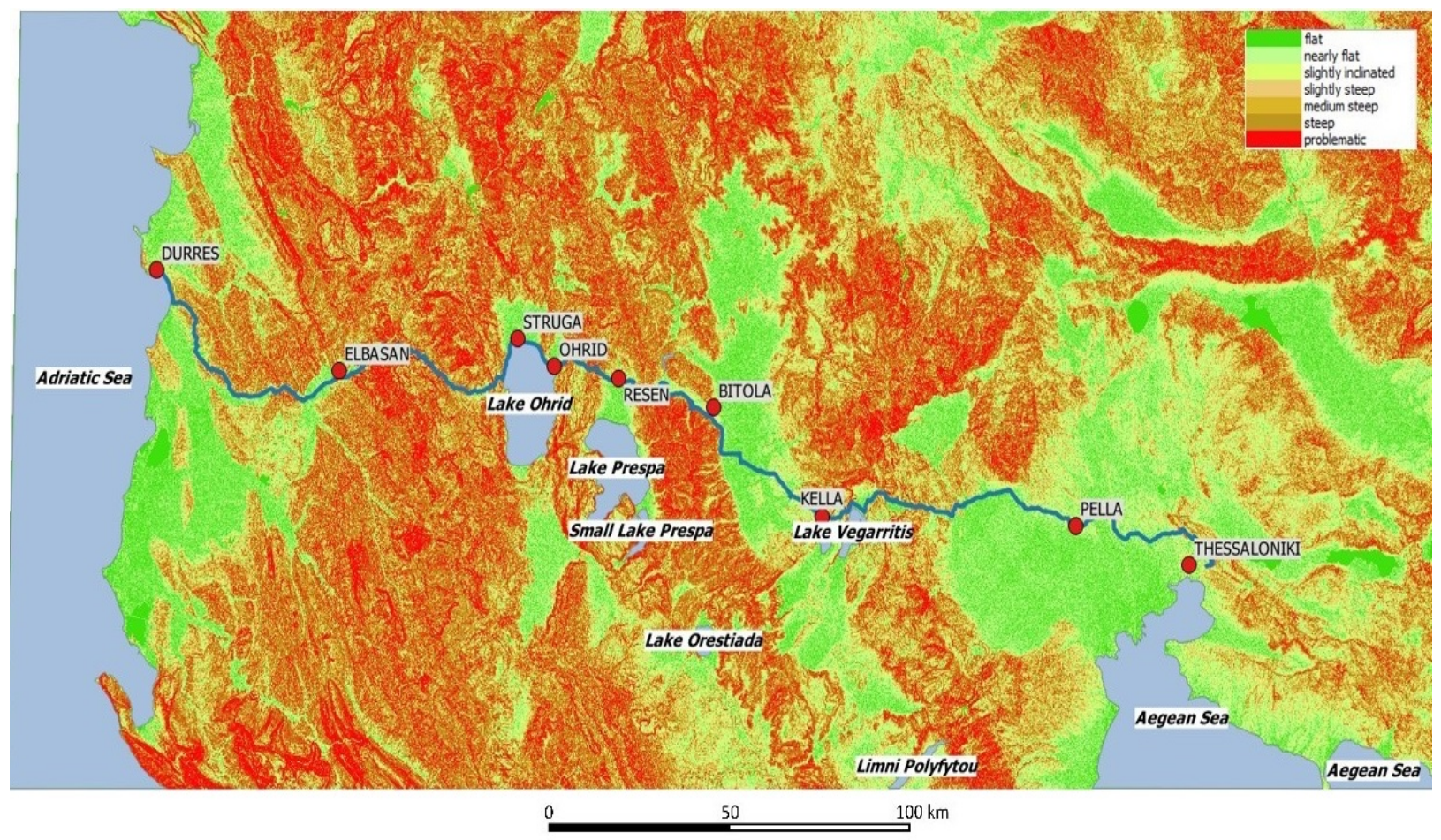

Figure 3. Overview of the gradient classes occurring in the study area

$\left(0^{\circ}-3^{\circ}=\right.$ flat, $>3^{\circ}-6^{\circ}=$ nearly flat, $>6^{\circ}-9^{\circ}=$ slightly inclinated, $>9^{\circ}-12^{\circ}=$ slightly steep,

$>12^{\circ}-15^{\circ}=$ medium steep, $>15^{\circ}-25^{\circ}=$ steep, $>25^{\circ}=$ problematic)

\section{RESULTS OF THE ANALYSIS,}

\section{APPLICATION AND EVALUATION}

In line with the underlying concept, 3D coordinates, inclination and curvature were calculated for any point representing the route. The statistical analysis showed that compared to the alternatives a sampling distance of $100 \mathrm{~m}$ is an excellent choice for modelling the Via Egnatia. The focus of the investigation is on the statistical description of the parameters considered important, i.e. inclination, height and curvature or their interaction.

The distribution of the height components [Fig. 4] of the route clearly shows that the path runs at low height for long stretches (1st quartile: lower than 70 $\mathrm{m})$ and $75 \%$ of the total length is below $700 \mathrm{~m}$. Furthermore, with regard to the sections, it is also apparent that primarily four altitude levels are affected: $0-200 \mathrm{~m}, 500-800 \mathrm{~m}$ and $900-1000$ meters. An equally clear picture is provided by the evaluation of the distribution of the gradients [Fig. 5], whereby it can be assumed that points with inclinations of more than $20^{\circ}$ are impassable and must therefore be regarded as artefacts. Apart from this, $25 \%$ of the positions have an inclination of less than $3^{\circ}$, although comparatively few segments are absolutely flat; $75 \%$ of the route is flatter than $10.5^{\circ}$ (approximately a slope of $18.5 \%$ ). A study of the relationship between elevation and slope [Fig. 6] illustrates in more detail the preferential zones in which the Via Egnatia runs in the study area $(0$ $100 \mathrm{~m}, 550-600 \mathrm{~m}, 650-750 \mathrm{~m}$, and at $800 \mathrm{~m}, 900$ $\mathrm{m}$ and $1000 \mathrm{~m}$ ).

The density of points at the level of $1550-1600 \mathrm{~m}$ is particularly striking, indicating a plateau position of the vertex of the route. The analysis of the behavior of the horizontal and vertical curvature (radii of curvature of terrain and road) as a function of sea level [Fig. 7 and Fig. 8] reflects on the one hand the characteristics of the investigated area through the density of points, but at the same time also allows the evaluation of the straightness of the route. 


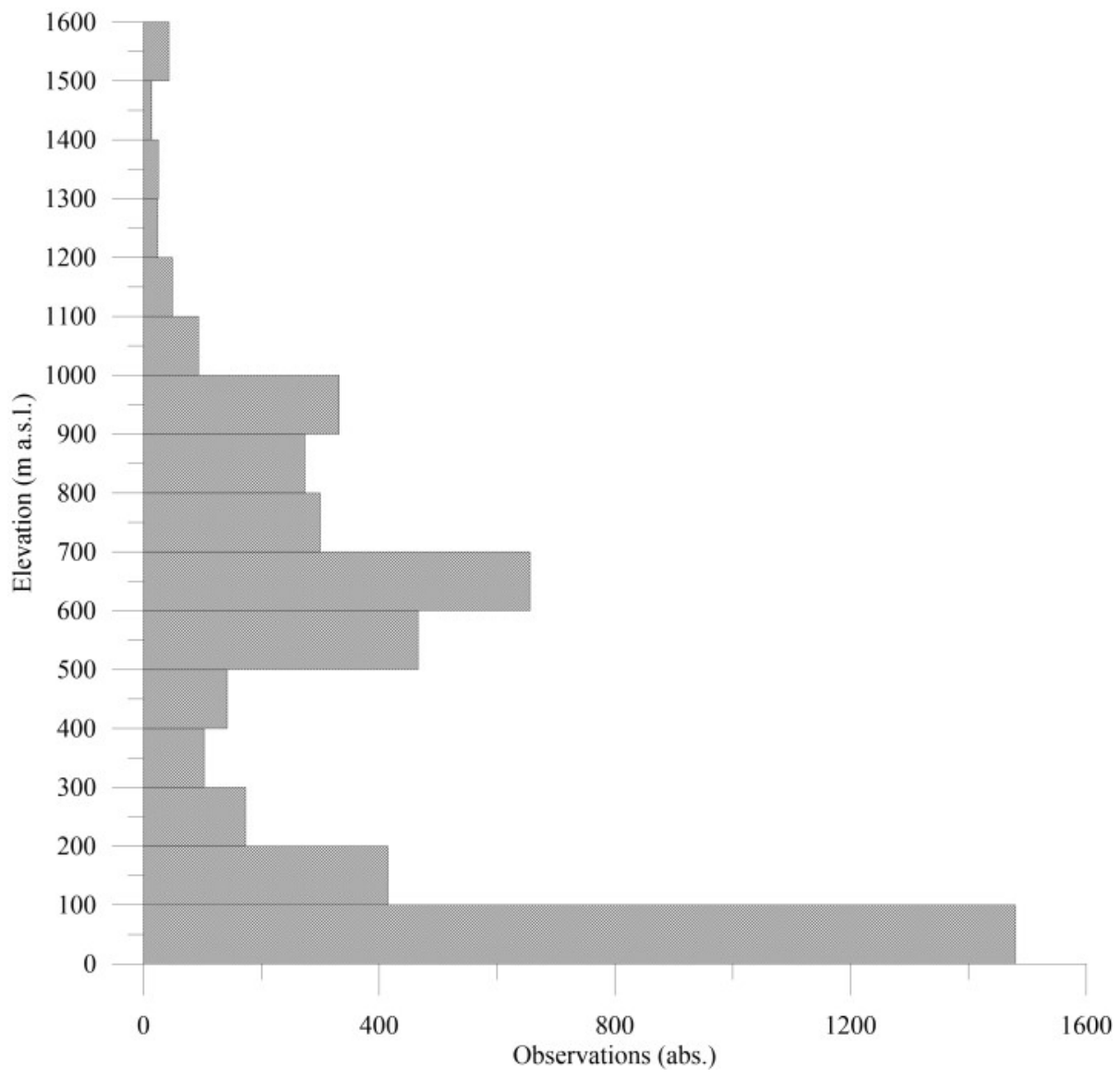

Figure 4. Frequency distribution of the elevation (classes of $100 \mathrm{~m}$ ).

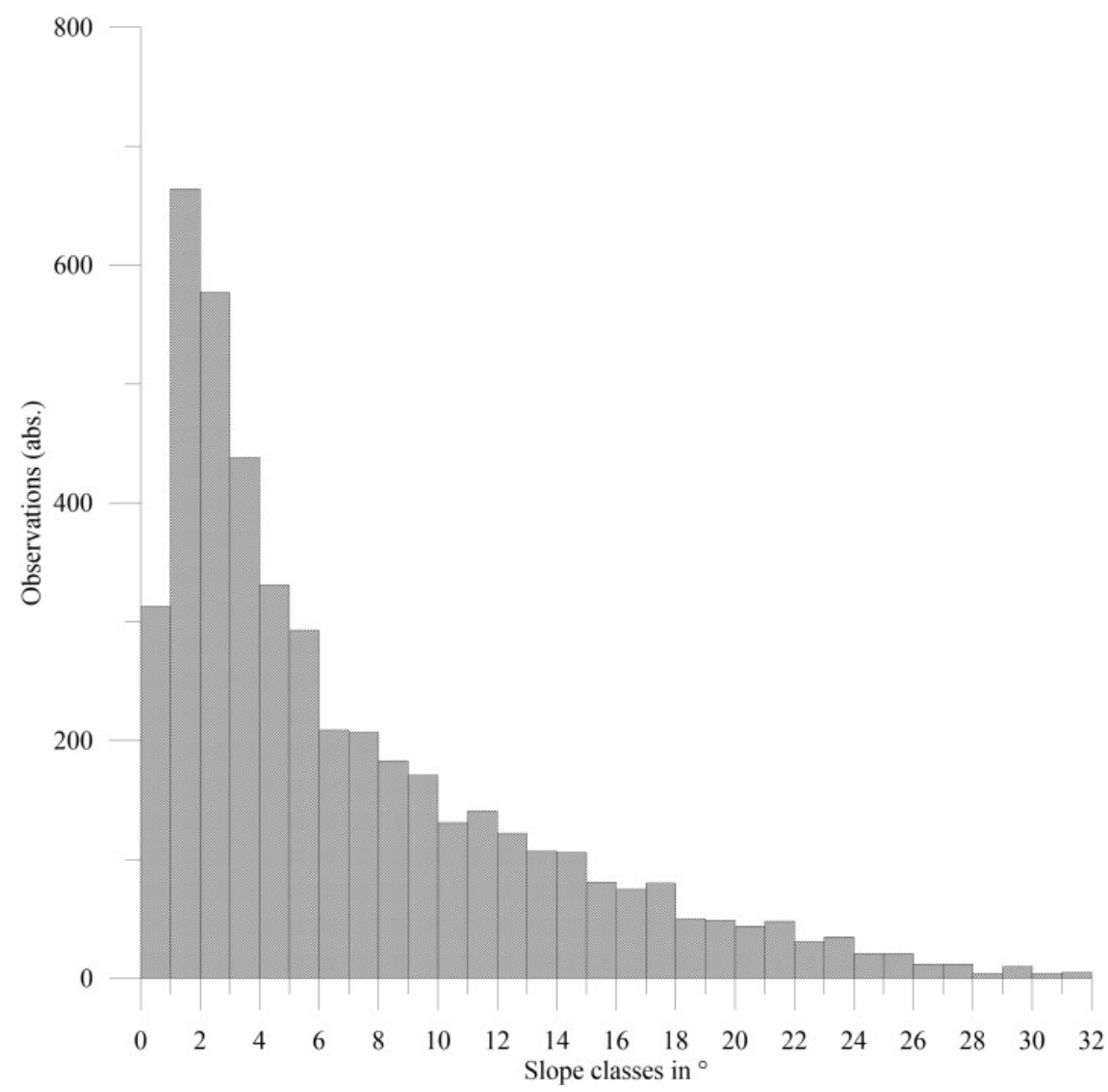

Figure 5. Frequency distribution of the slope. 


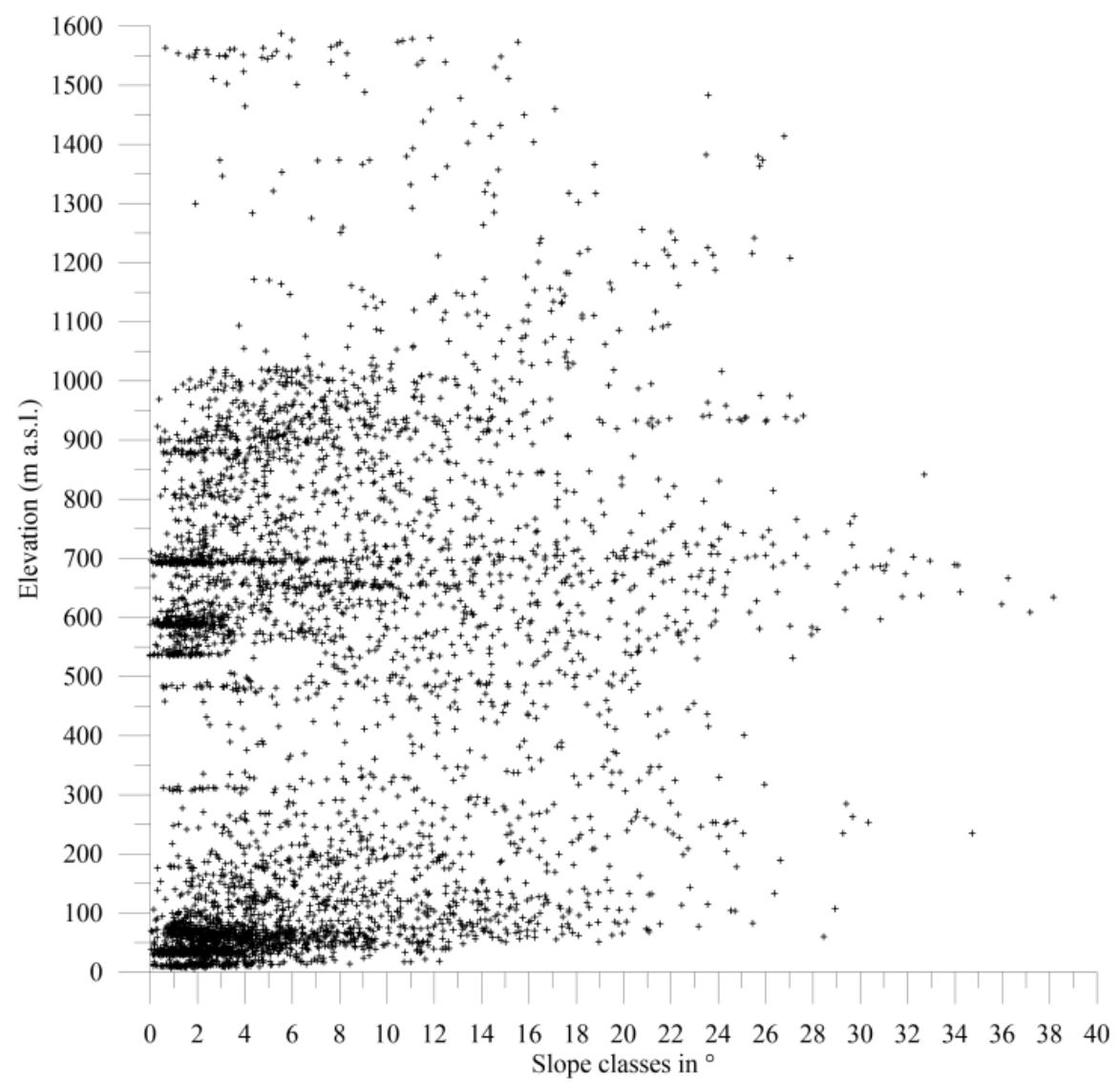

Figure 6. Relationship between elevation and slope.

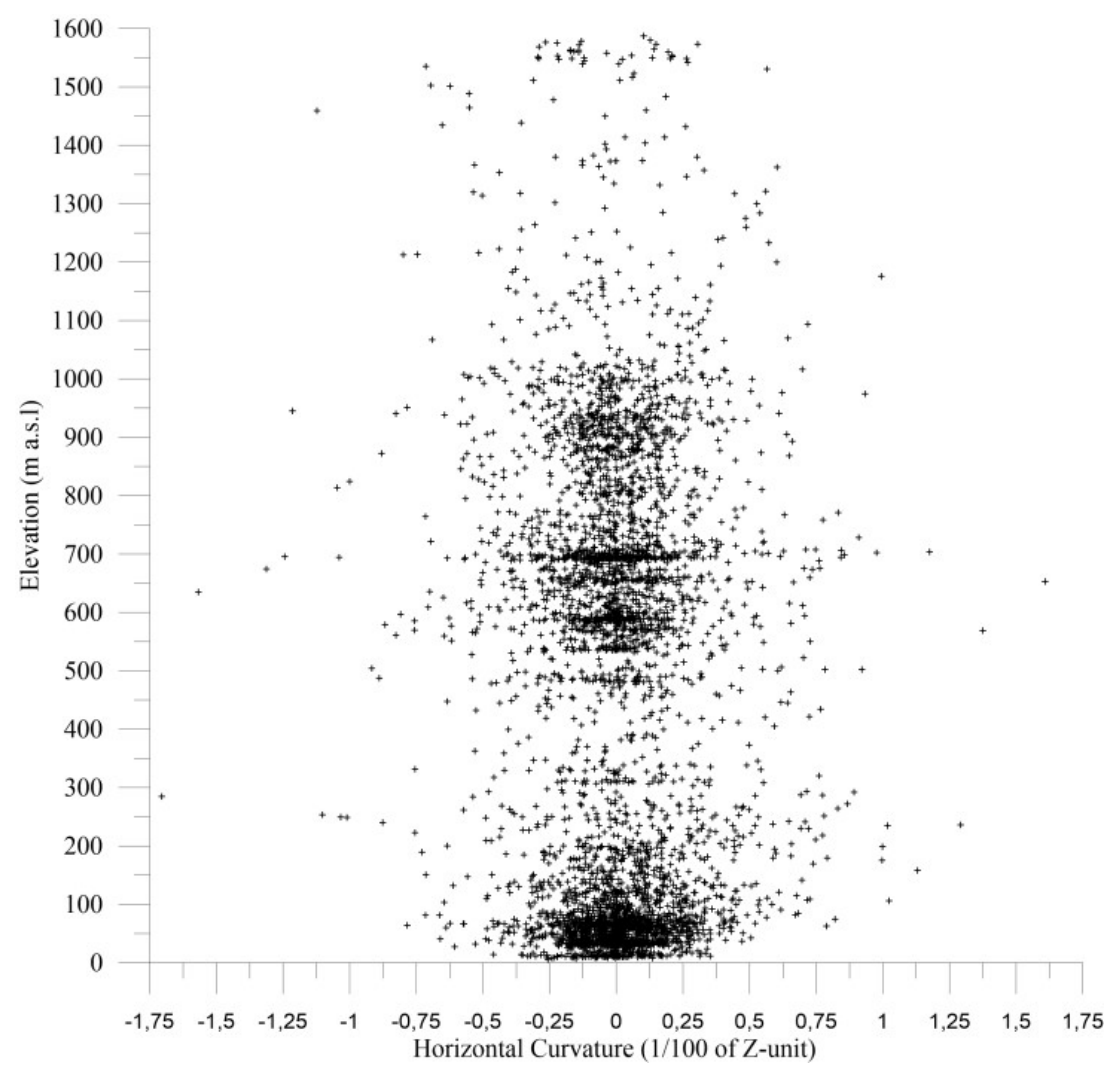

Figure 7. Relationship between elevation and horizontal curvature. 


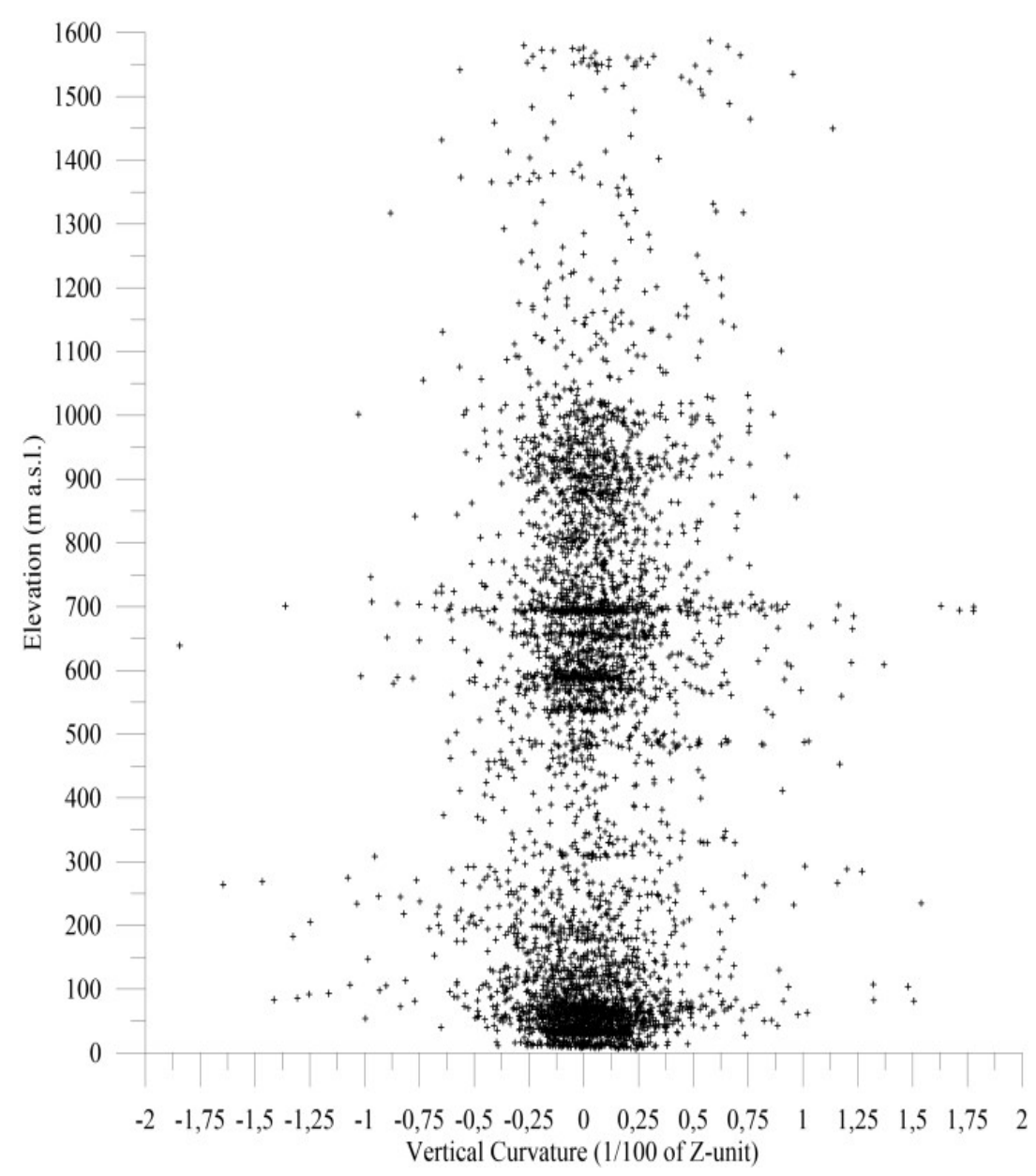

Figure 8. Relationship between elevation and vertcal curvature.

The fact that the curves in hilly terrain can assume values between +2 and -2 and in high mountains values between +4 and -4 allows a first overview assessment. In addition to this, medians (horizontal: 0.000; vertical: 0.016 ) and the corresponding interquartile distances (h: $-0.109-0.117$; v: -0.098 - 0.151) indicate that the investigated segments usually show only very little curvature. The evaluation of the determined parameters was carried out with the help of a standardized procedure, which carries out the search for the optimal route on the basis of certain given basic conditions, whereby a polyline or point solution is determined on the basis of a DTM raster. Characteristic values derived from the previous terrain parameterization serve as control variables; in concrete terms, permitted value ranges for the gradients (gradient and slope) and for the radii of curvature were defined. To make the system more flexible, a weighting of these factors with penalty points was implemented additionally. To reduce the computational time, further possibilities were created: the consideration of given control points (e.g. secured finding places) and the avoidance of certain areas (e.g. swamps) by exclusion polygons. Fig. 9 graphically shows the result of the test for the mountainous area of the Via Egnatia east of Ohrid. It turns out that the predicted route hardly deviates anywhere further than $15-30 \mathrm{~m}$ from the original track; however, especially in impassable terrain this distance can be much greater $(130-480 \mathrm{~m})$. This is mainly due to sampling artefacts or errors in the implementation of the parameters in the evaluation model, the elimination of which will be the subject of further investigations. 


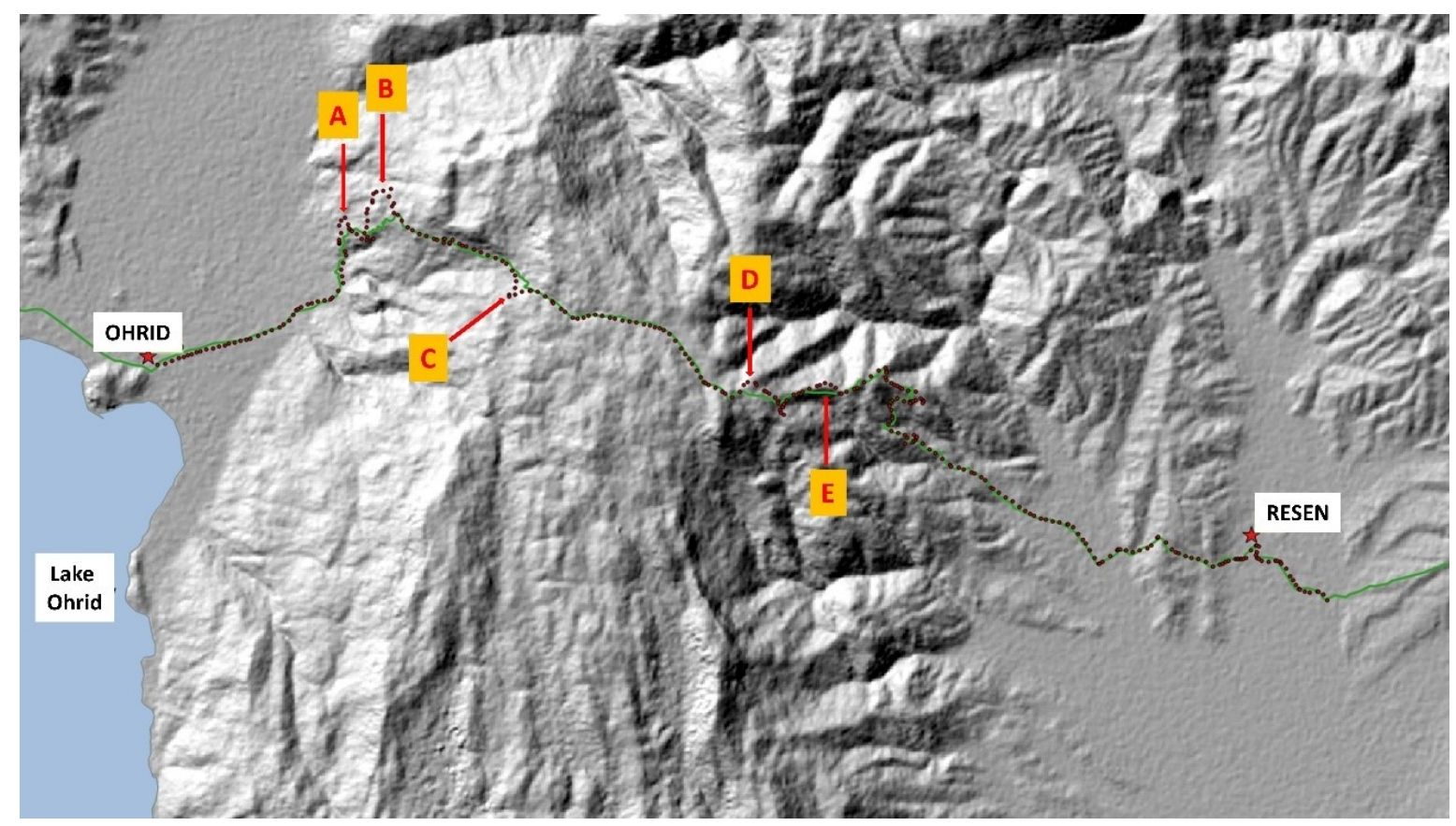

Figure 9. Result of the simulation based on the parametrization of the relief

(green solid line $=$ original route, red dotted line $=$ approximation; the capitals indicate spots of extreme deviation; A: 149 m, B: 483 m, C: 284 m, D: 191 m and E: 138 m)

\section{REFERENCES:}

[1] Verhagen, Ph., Nuninger, L. Groenhuijzen, M., Modelling of Pathways and Movement Networks in Archaeology: An Overview of Current approaches, in Finding the Limits of the Limes. Modelling Demography, Economy and Transport on the Edge of the Roman Empire, Ph. Verhagen, J. Joyce, M. Groenhuijzen (Eds.), Berlin, New York, pp 216-249, 2019.

[2] Hammond, N.G.L., The Western Part of the via Egnatia, The Journal of Roman Studies, Vol. 64, pp 185-194, 1974.

[3] Edson, Ch., THE LOCATION OF CELLAE AND THE ROUTE OF THE VIA EGNATIA IN WESTERN MACEDONIA, CLASSICAL PHILOLOGY Vol XLVI, Number 1, pp 1-16, 1951.

[4] Lolos, Y., Via Enatia after Egnatius: Imperial Policy and Inter-regional Contacts, Mediterranean Historical Review Vol. 22, No. 2, pp 273-293, 2007.

[5] Walbank, F, W., VIA ILLA NOSTRA MILITARIS: SOME THOUGHTS ON THE VIA EGNATIA, in Althistorische Studien: Hermann Bengtson zum 70. Geburtstag dargebracht, Wiesbaden, pp 137-147, 1983.

[6] van Attekum, M. \& de Briun, H., Via Egnatia on foot. A journey into history. Part 1 from Durres to Thessaloniki. Via Egnatia Foundation, Driebergen, 256 p, 2017.

[7] Fasolo, M., La Via Egnatia I, Da Appollonia e Dyrrachium ad Herakleia Lynkestidos, Viae Publicae Romanae 1, 287 p, 2005.

[8] de Matteis, M., Pierini, R. \& Riska, A., Da Durazzo e Apollonia a Ohrid. Documentazione fotografica / Nga Durrësi dhe Apollonia në Ohër. Dokumentim fotografik / Von Durres und Apollonia nach Ohrid. Fotografische Dokumentation. Deutsch-Italienisch, Cultura, italiana in contesto europeo 5, Athena, 104 p, 2016.

[9] Flitter, H. \& Weibel, R., Erreichbarkeit, Geographic Information Technology Training Alliance, pp 6-9, 2006. http://www.gitta.info/Accessibilit/de/text/Accessibilit.pdf, last accessed: 20.02.2020

[10] Trautwein, F., Flitter, H., Weibel, R. \& Hägi, S., Geländeanalyse, Geographic Information Technology Training Alliance, pp 9-12, 2006. http://www.gitta.info/TerrainAnaly/de/text/TerrainAnaly.pdf last accessed: 20.02.2020

[11] Environmental Research System Incorporated, 'Creating a cost surface Raster', 2014. $\mathrm{http} / / /$ desktop.arcgis.com/en/arcmap/10.3/tools/spatial-analyst-toolbox/creating-a-cost-surface-raster.html, last accessed: 20.02.2020. 
[12] Bell, T. and Lock, G., 'Topographic and cultural influences on walking the Ridgeway in later prehistoric times', in G. Lock (Ed.) Beyond the Map. Archaeology and Spatial Technologies, Amsterdam, Berlin, Oxford, Tokyo, Washington DC, pp 85-100, 2000.

[13] Herzog, I., A REVIEW OF CASE STUDIES IN ARCHAEOLOGICAL LEAST-COST ANALYSIS, Archeologia e Calcolatori 25, pp 223-239, 2014.

[14] Pingel, T.J., Modeling Slope as a Contributor to Route Selection in Mountainous Areas, in Cartography and Geographic Information Science, 37:2, DOI: 10.1559/ 152304010791232163, pp 137-148, 2010.

[15] Herzog, I. Yepes, A., The impact of the DEM on archaeological GIS studies. A case study in Ecuador, Proceedings of the 20th CHNT, Vienna, pp 1-18, 2015.

[16] Carreras, C., de Soto, P. \& Munoz, A., Land transport in mountainous regions in the Roman Empire: Network analysis in the case of the Alps and Pyrenees, Journal of Archaeological Science: Reports 25, pp 280-293, 2019.

[17] Wu, J., Yang, Q. \& Li, Y., Partitioning of Terrain Features Based on Roughness, in Remote Sensing, 10, 1985; DOI:10.3390/ rs10121985, pp 1-21, 2018. 